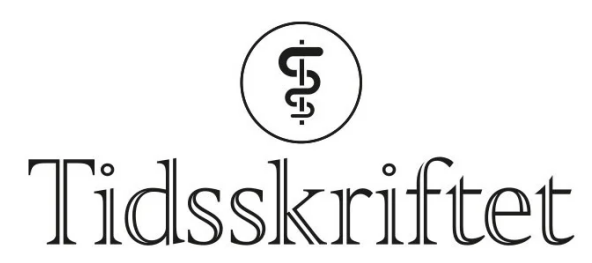

DEN NORSKE LEGEFORENING

\title{
Avhengig lege
}

LEGELIVET

\section{MARTE SYVERTSEN}

marsyv@vestreviken.no

Marte Syvertsen er lege i spesialisering og forsker ved Nevrologisk avdeling i Vestre Viken, Drammen.

\section{Her kommer en kasuistikk der legen, pasienten og skribenten er én og samme person.}

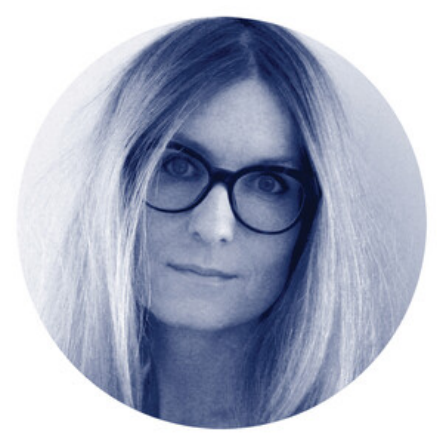

Foto: privat

Bakgrunnen er at avhengighet er en vanskelig sak. Vi støter stadig på det: litt for mye benzodiazepiner, litt for mye alkohol, nikotin eller enda sterkere stoffer. Det kan også være for mye spill, for mye trening eller for mye jobb. En fellesnevner er at hjernen frigjør deilig dopamin, og da vil vi ha mer av det samme. I neste omgang kommer de rent kroppslige reaksjonene, når systemene inni deg har tatt opp dette vanedannende, hva det enn er, som en del av deg selv. Da blir det gapende tomt hvis noen plutselig tar det vekk. Vi vet alle hva det innebærer, i alle fall rent teoretisk.

«Når systemene inni deg har tatt opp dette vanedannende, da blir det gapende tomt hvis noen plutselig tar det vekk»

Kaffe er et stoff forskere liker. Det er sunt. Det er ikke sunt. Kan det fremprovosere epileptiske anfall? Antakelig ikke. Kan gravide drikke kaffe? Nei, ikke for mye. Kan kaffe ha en nevroprotektiv effekt? Kanskje. Jeg husker en av professorene på medisinstudiet ved NTNU. Hun drakk overhodet ikke kaffe. Det er det eneste jeg husker fra den forelesningen. Hennes spesialitet var nevrotransmittere. Hun var kanskje den i Norge som kunne ha aller best innsikt i hva kaffe egentlig gjør med hjernen. 
Metoden i denne kasuistikken er å presentere en pasient som muligens har et litt for høyt inntak av kaffe. Men det har hun naturligvis full kontroll på. Det er bare å ikke drikke kaffe, når som helst. Derfor skulle hun gjennomføre en hvit uke, altså en hel uke uten denne brune, duftende, oppkvikkende og hyggelige drikken.

Dag 1 begynte ganske bra. Hun satte seg ved datamaskinen på hjemmekontoret. Dette var i perioden da alle jobbet hjemmefra, såfremt det lot seg gjøre. Der kom det første suget etter en kaffekopp. Ah, det hadde vært så fint å holde i den gode, solide koppen og ta noen små lunkne slurker mens hun møysommelig jobbet seg gjennom dagens uleste e-poster. Heldigvis gjenkjente pasienten fenomenet som klassisk craving. Her var vi i en typisk setting hvor det etterlengtede middelet vanligvis ble inntatt. Slikt psykologisk lureri skulle hun lett motstå, tenkte hun, mens hun knatret videre på tastaturet. Dermed var dag 1 nokså enkelt overstått.

Formiddagen dag 2 forløp omtrent på samme måte, men etter lunsj ble det verre. Hodepinen kom snikende og satte seg som en klo rundt halsen. Klokken 13 hadde pasienten et telefonintervju med en journalist fra et velrenommert psykologisk tidsskrift. Det ble gjennomført mens hun halvveis lå utover en kjøkkenstol, med nakken hvilende på stolryggen. Forhåpentligvis merket journalisten ingenting.

Dag 3 var hodepinen der allerede fra morgenen av. Pasienten satte seg ved tastaturet, klar for første Zoom-møte klokka 9 med professoren ved Spesialsykehuset for epilepsi og en forskerkollega. Underveis i møtet bygget smerten i hodet seg opp til et nærmest uutholdelig nivå. Samtidig steg kvalmen som en bølge fra mellomgulvet. Det begynte å bli vanskelig å holde masken. Plutselig måtte hun rømme fra skjermen, hive seg over kjøkkenvasken og levere hele frokosten ned i det blanke, rustfrie stålet. Tilbake ved skjermen unnskyldte hun seg spakt for den brå forsvinningen.

\section{«Med senket hode beveget pasienten seg mot kaffemaskinen på benken»}

Møtet ble kort. Med senket hode beveget pasienten seg mot kaffemaskinen på benken. Hun trykket på knappen med en skjelvende finger og så den lysebrune væsken sildre ned $\mathrm{i}$ koppen. Hun klamret seg til koppen på vei bort til sofaen, satte den forsiktig på glassbordet og la seg ned med lukkede øyne mens hun ventet på at koppen skulle avkjøles litt. Så drakk hun kald kaffe, sakte, med sugerør, for å unngå å løfte hodet. Det var et stusselig scenario. Men roen fant veien tilbake, og ikke lenge etter lettet den altoppslukende hodepinen som en tåkesky om morgenen. Det var intet mindre enn befriende, i bokstavelig forstand.

Endepunktet var altså at den hvite uken gikk på en real sprekk. Pasienten klarte ikke mer enn to dager før hun vendte tilbake til substansen hun skulle holde seg borte fra. Innsikt i all verdens nevrologiske og andre kroppslige mekanismer for avhengighet, reddet henne ikke. Hun hadde endatil skrevet en bok hvor dette var et av temaene.

Hvilke konklusjoner kan vi trekke? Det er så altfor lett å strekke hånden ut for å få tak i dette ene som kan ta vekk alt ubehaget. Alle som sliter med avhengighet og alt det fører med seg, fortjener dyp og ektefølt respekt. At dere klarer det, når ovenfornevnte pasient ikke engang kunne stå i to dager uten kaffe, er det bare å bøye seg i støvet for.

Ikke still på Zoom-møter med ukjent varighet hvis du er på vei inn i kaffeabstinens.

Publisert: 10. august 2021. Tidsskr Nor Legeforen. DOI: 10.4045/tidsskr.21.056o

(C) Tidsskrift for Den norske legeforening 2023. Lastet ned fra tidsskriftet.no 26. april 2023. 